\title{
THE EFFECT OF AMPHOTERICIN B ON THE LIFESPAN, BODY-SURFACE PROTEIN CONCENTRATIONS, AND DNA METHYLATION LEVELS OF HONEY BEES (Apis mellifera)
}

\author{
Aneta Strachecka ${ }^{1}$, Grzegorz Borsuk ${ }^{\mathbf{1}}$, \\ Krzysztof Olszewski ${ }^{1}$, Jerzy Paleolog ${ }^{1}$, \\ Mariusz Gagoś ${ }^{2}$, Jacek Chobotow ${ }^{3}$, \\ Agnieszka Nawrocka ${ }^{4}$, Magdalena Gryzińska ${ }^{1}$, \\ Milena $B$ ajda ${ }^{1}$ \\ ${ }^{1}$ Department of Biological Basis of Animal Production, \\ Faculty of Biology and Animal Breeding, University of Life Sciences in Lublin, \\ Akademicka 13, 20-950 Lublin, Poland \\ ${ }^{2}$ Department of Biophysics, University of Life Sciences in Lublin, \\ Akademicka 13, 20-950 Lublin, Poland \\ ${ }^{3}$ Department of Zoology, Institute of Biology and Biochemistry, \\ Faculty of Biology and Biotechnology, Akademicka 19, 20-033 Lublin, Poland \\ ${ }^{4}$ Laboratory of Assessment of Grain and Oil Materials Quality, \\ Institute of Agrophysics, Polish Academy of Sciences in Lublin, \\ Doświadczalna 4, P.O. Box 201, 20-290 Lublin, Poland \\ e-mail: aneta.strachecka@up.lublin.pl \\ Received 14 September 2012; accepted 19 November 2012 \\ $\mathrm{S}$ u m m a r y
}

Three groups of caged bees were fed with sugar syrup (the control), sugar syrup supplemented with amphotericin $B(A m B)$ in a dose of $0.5 \mathrm{mg} / \mathrm{ml}$, and sugar syrup with $A m B$ in a dose of $0.25 \mathrm{mg} / \mathrm{ml}$. Amphotericin B shortened the life span of the bees and reduced the level of global DNA methylation compared to the control, however, it increased the body-surface protein concentrations. In the hindguts of the bees, there were found AmB deposits. Honeybees appear to be a useful model for studying the side effects of anti-fungal AmB therapy. Among other things, epigenetic changes and senescence acceleration are considered to be the side effects of the therapy.

Keywords: amphotericin B, Apis mellifera, DNA methylation, life-span, protein concentration.

\section{INTRODUCTION}

Amphotericin B (AmB) is a macrolide polyene antibiotic which is very efficient in the treatment of deep-seated mycotic infections but has toxic side effects. Nevertheless, the application of AmB to treat several mycoses of internal organs occurring in the aftermath of AIDS (Konopka et al., 1999; Krukowski et al., 2010) and for internal organ transplants is experiencing its renaissance (Hartsel and Bolard, 1996). We simply have to choose the "lesser evil".
It is accepted, that the biological effect of $\mathrm{AmB}$ is based on the interaction with cellular membranes and particularly on the formation of transmembrane pores that are able to seriously affect the physiological ion transport. However, precise mechanisms responsible for both therapeutic and toxic side effects of AmB are still not fully understood. Numerous side effects, such as nephrotoxic activity, hepatotoxic activity, and in higher doses - neurotoxic and hemolytic activities are induced by $\mathrm{AmB}$ (Gallis et al., 1990). One of the main 
problems of AmB treatment is related to its aggregation (Espada et al., 2008; Gagoś et al., 2011). It was recently found by Gagoś et al. (2011), that the formation of $\mathrm{AmB}-\mathrm{Cu}^{2+}$ complexes is linked to the disaggregation of $\mathrm{AmB}$. This may facilitate practical applications of AmB.

There are two strategies in fighting apian mycosis, i.e. the use of medicine and taking advantage of apian behavioural resistance (Chorbiński, 2004). The chemical agents in use include disinfectants, organic acids, plant extracts, and antifungal drugs e.g. AmB (Kostecka and Niewiadomy, 2010). However, veterinarian regulations do not allow the use of antibiotics in Nosema spp. treatment in the EU. On the other hand, there is an increasing problem with the Nosema ceranae invasion in Europe (Ptaszyńska et al., 2012a, b). There are kept bee populations that must not be lost (e.g. De la Rua et al., 2009). In order to better use AmB in humans, and also to enable the restricted use of $\mathrm{AmB}$ in bees (the lesser evil), we have to learn more about the functioning of this drug in living organisms.

Apis mellifera has been found to be a unique model for some biochemical and genetic studies of vertebrates and humans (Burzyński, 2009; Paleolog et al., 2011; Strachecka et al., 2012c). Contrary to the commonly used Drosophila, it has the advantage of a large organismal size (Munch et al., 2008). It is not only the genome content that determines the functions of living organisms. An important role is also played by the gene-silencing molecular switches - the epigenome that is sometimes more important for heredity than the DNA code (Burzyński, 2009). Lyko and Maleszka (2011) have shown that honeybees are a good model for the epigenetic study of vertebrates. They can store epigenetic information and perform DNA methylation processes (basic for epigenetic genome regulation) in a way similar to humans (Kucharski et al., 2008; Maleszka, 2008).

Considering the global problems with mycosis, and considering the only partially known harmful side effects of the AmB therapy in humans, and especially the lack of information about the consequences of AmB use for genome methylation (epigenetic regulation), we studied how amphotericin B affects the life span, global DNA 5-methylocytosine (m5C) content, and cuticle surface protein concentration in bees. We also focused our study on the location of amphotericin B molecules in the body of honeybees, using honeybees as model organisms. The studies also offered the opportunity to increase the chances of a restricted use of $\mathrm{AmB}$ in honeybees.

\section{MATERIAL AND METHODS}

Three bee groups were set up: 10 wooden cages $(12 \times 12 \times 4 \mathrm{~cm})$ with 50 one-dayold worker bees in each of the groups. The cages had glass front screens but they had no combs or wax foundations inside. The sugar syrup (1:1) was administered ad libitum via inner feeders. In the first group (AmB-25), the syrup was supplemented with amphotericin B (AmB; Sigma Aldrich) at a concentration of $0.25 \mathrm{mg} / \mathrm{ml}$, in the second group (AmB-50) at a concentration of $0.50 \mathrm{mg} / \mathrm{ml}$, whereas in the third group which was the control, $\mathrm{AmB}$ was not added. The cages were kept within an air-conditioned chamber $\left(26^{\circ} \mathrm{C}\right.$ and $\left.65 \% \mathrm{RH}\right)$. Every two days, the feeders were replenished with the syrup. Dead workers were removed from the cages and divided into 4 sets: 1 - to assess Nosema spp. infestation, 2 - to detect AmB aggregations in the apian bodies, 3 - to isolate DNA and analyse its methylation, 4 - to determine protein concentration. Set 1 and set 2 were directly processed. The other two sets were frozen $\left(-25^{\circ} \mathrm{C}\right)$. Each set contained approximately 125 bees.

Set 1: The extent of Nosema spp. infestation was assessed as described by Pohorecka (2004).

Set 2: The workers were X-rayed using the Faxitron MX-20 system for biological material structures. When irradiated, AmB aggregations should emit a fluorescent glow. Subsequently, the workers treated with AmB-50 and AmB-25 were incised 
under the Olympus SZX16 Stereo Zoom Microscope: (camera: Olympus DP72). We looked for aggregations of $\mathrm{AmB}$ in the apian bodies, and when they were found, we photographed them.

Set: 3: After defrosting, DNA was extracted from the workers' heads and thoraces using the DNeasy Blood \& Tissue Kit (Qiagen) according to the producer's procedure. Extracted DNA samples were stored at $-25^{\circ} \mathrm{C}$ and subsequently modified by treatment with Capture Antibody using the MDQ1-96RXN Imprint $\AA$ Methylated DNA Quantification Kit (Sigma; producer's procedure).

Set 4: The workers were defrosted. Next, they were rinsed in $10 \mathrm{ml}$ of distilled water for 20 seconds to remove impurities. The Lowry method modified by Schacterle and Pollack (1973) was used. Since the rinsings were found to contain no proteins, they were discarded. Subsequently, the workers were put into test tubes ( 5 insects in each; 24 samples per group), $10 \mathrm{ml}$ of a $1 \%$ detergent: water solution (Triton $\mathrm{X}-100$ ) was added and the bees were shaken/rinsed again for $10 \mathrm{~min}$. at $3400 \mathrm{rpm}$. After filtrating each of the samples through Miracloth, concentrations of the proteins isolated from the apian cuticles were determined as described above.
The significance of the $\mathrm{AmB}$ effects and differences between the average trait values were investigated with oneway ANOVA and LSD procedures using SAS statistical software (SAS Institute Version 9.13., 2002-2003 license 86636). The statistical calculations were performed using numbers transformed according to arcsine transformation.

\section{RESULTS}

Compared to the control group, the bees treated with AmB-25 and AmB-50 lived shorter (Tab. 1) but they were not infested with Nosema spp. (AmB-50: $0 \pm 0$ [120]; Amb-25: $0 \pm 0$ [125]; the control: $29 \pm 2.01[120]$ spores).

The $\mathrm{X}$ - ray system detected $\mathrm{AmB}$ as bright, shiny spots in the AmB-25 and AMB-50 workers (Fig. 1A). It was also found as yellow spots/clusters in their hindguts (Fig. 1B) with the Stereo Zoom Microscope. There was no absorption (no AmB aggregations) in the cavities of the body, haemolymph, etc.

The level of global DNA methylation in the one-day-old workers (the first day of the study) was the same in all the groups (AmB-50: $6.25 \pm 0.002$ [10]; AmB-25: $6.25 \pm 0.003$ [10]; the control: $6.25 \pm 0.003[10])$. In comparison with the control, AmB significantly decreased DNA
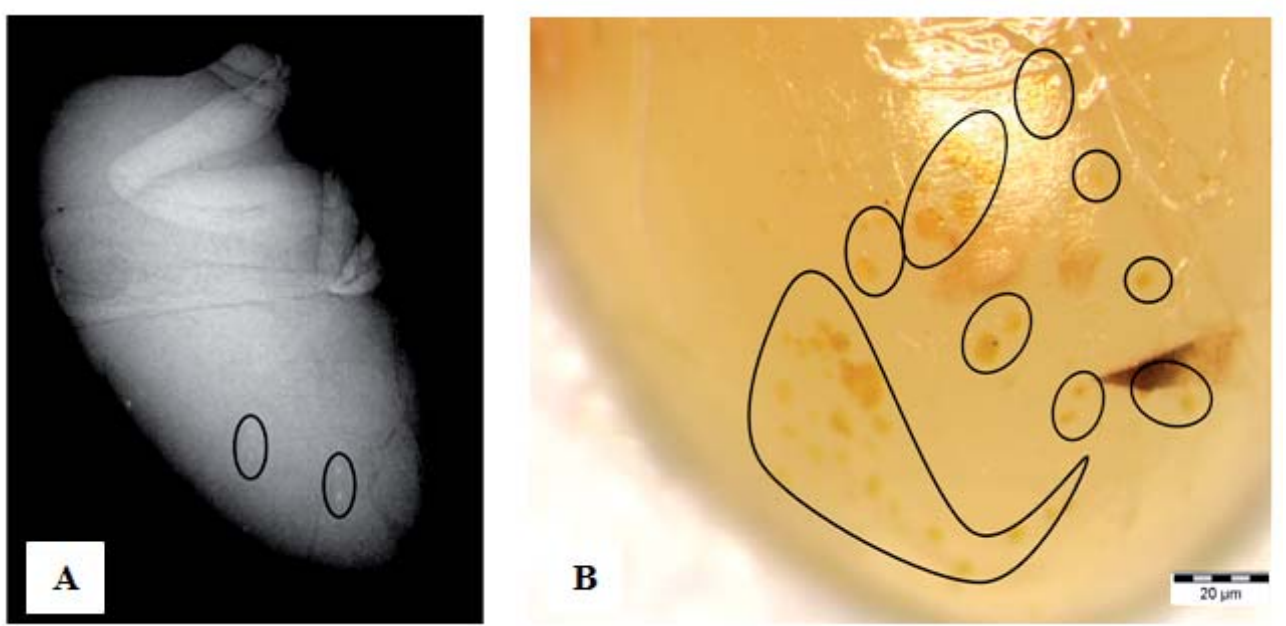

Fig. 1. Location of amphotericin $\mathrm{B}(\mathrm{AmB})$ in the hindgut of the A. mellifera workers. A: X-ray system image; B: Stereo zoom microscope image. 
Mortality of caged worker bees expressed

in percentiles of the life-span distribution

\begin{tabular}{||c|c|c|c|c|c|c|c|c|c||}
\hline \multirow{3}{*}{ Group } & \multirow{6}{*}{$\mathrm{n}$ [cages] } & \multicolumn{6}{|c|}{$\begin{array}{c}\text { The day on which the following percentages } \\
\text { of the caged workers were still alive: }\end{array}$} \\
\cline { 3 - 10 } & & \multicolumn{2}{|c|}{$70 \%$} & \multicolumn{2}{|c|}{$50 \%$} & \multicolumn{2}{|c|}{$30 \%$} & \multicolumn{2}{|c|}{$0 \%$} \\
\cline { 3 - 10 } & & $\bar{x}$ & $\pm \mathrm{se}$ & $\bar{x}$ & $\pm \mathrm{se}$ & $\bar{x}$ & $\pm \mathrm{se}$ & $\overline{\times}$ & $\pm \mathrm{se}$ \\
\hline The control & 10 & $16 \mathrm{~b}$ & 1.03 & $21 \mathrm{~b}$ & 0.80 & $25 \mathrm{~b}$ & 0.79 & $36 \mathrm{~b}$ & 0.76 \\
\hline AmB-25 & 10 & $13 \mathrm{a}$ & 0.54 & $16 \mathrm{a}$ & 0.70 & $20 \mathrm{ab}$ & 1.03 & $28 \mathrm{a}$ & 1.26 \\
\hline AmB-50 & 10 & $12 \mathrm{a}$ & 0.87 & $15 \mathrm{a}$ & 0.90 & $19 \mathrm{a}$ & 1.12 & $27 \mathrm{a}$ & 1.96 \\
\hline \hline
\end{tabular}

Various lowercase letters - the differences are statistically significant at $\mathrm{P} \leq 0.05$ for comparisons within the columns (between the control and AmB-25 and AmB-50);

$\bar{x}$ - mean value;

\pm se - standard error;

AmB-25 - the workers were treated with $0.25 \mathrm{mg} / \mathrm{ml}$ amphotericin B;

AmB-50 - the workers were treated with $0.50 \mathrm{mg} / \mathrm{ml}$ amphotericin B.

Table 2 .

Global DNA methylation level (\%)

in workers treated with amphotericin B $(\mathrm{AmB})$

\begin{tabular}{||c|c|c|c|c|c|c|c|c|c||}
\hline \multirow{2}{*}{ Group } & \multirow{2}{*}{$\begin{array}{c}\mathrm{n} \text { [workers in } \\
\text { each period] }\end{array}$} & \multicolumn{2}{|c|}{$\begin{array}{c}\text { 1-week-old } \\
\text { workers }\end{array}$} & \multicolumn{2}{c|}{$\begin{array}{c}\text { 2-week-old } \\
\text { workers }\end{array}$} & \multicolumn{2}{c|}{$\begin{array}{c}\text { 4-week-old } \\
\text { workers }\end{array}$} & \multicolumn{3}{|c|}{$\begin{array}{c}\text { 5-week-old } \\
\text { workers }\end{array}$} \\
\cline { 3 - 11 } & & $\bar{x}$ & $\pm \mathrm{se}$ & $\bar{x}$ & $\pm \mathrm{se}$ & $\bar{x}$ & $\pm \mathrm{se}$ & $\overline{\mathrm{x}}$ & $\pm \mathrm{se}$ \\
\hline The control & 30 & $6.98 \mathrm{a}$ & 0.004 & $7.46 \mathrm{a}$ & 0.005 & $14.96 \mathrm{a}$ & 0.004 & $22.49 \mathrm{a}$ & 0.005 \\
\hline AmB-25 & 30 & $6.12 \mathrm{~b}$ & 0.002 & $6.76 \mathrm{~b}$ & 0.005 & $10.7 \mathrm{~b}$ & 0.003 & $10.8 \mathrm{~b}$ & 0.005 \\
\hline $\mathrm{AmB}-50$ & 30 & $5.91 \mathrm{c}$ & 0.004 & $1.15 \mathrm{c}$ & 0.005 & $3.72 \mathrm{c}$ & 0.004 & $4.41 \mathrm{c}$ & 0.004 \\
\hline
\end{tabular}

Various lowercase letters - the differences are statistically significant for comparisons in the columns (between the control and AmB-25 and AmB-50) at $\mathrm{P} \leq 0.05$;

$\bar{x}$ - mean value;

\pm se - standard error;

AmB-25 - the workers were treated with $0.25 \mathrm{mg} / \mathrm{ml}$ amphotericin B;

AmB-50 - the workers were treated with $0.50 \mathrm{mg} / \mathrm{ml}$ amphotericin B.

No statistically significant differences were observed between the samples in a specific period

(2-3 samplings per week).

Table 3 .

Protein concentrations $(\mathrm{mg} / \mathrm{ml})$ on the body surface of A. mellifera workers treated with amphotericin B (AmB)

\begin{tabular}{|c|c|c|c|c|c|c|c|}
\hline \multirow{2}{*}{ Group } & \multirow{2}{*}{$\begin{array}{l}\mathrm{n} \text { [workers in } \\
\text { each period] }\end{array}$} & \multicolumn{2}{|c|}{$\begin{array}{c}\text { 1-day-old - } 2 \\
\text {-week-old workers }\end{array}$} & \multicolumn{2}{|c|}{$\begin{array}{l}\text { 3-4 - week-old } \\
\text { workers }\end{array}$} & \multicolumn{2}{|c|}{$\begin{array}{l}5 \text {-week-old } \\
\text { workers }\end{array}$} \\
\hline & & $\bar{x}$ & \pm se & $\bar{x}$ & \pm se & $\overline{\bar{x}}$ & \pm se \\
\hline The control & 40 & $0.104 b$ & 0.03 & $0.122 b$ & 0.04 & $0.026 \mathrm{~b}$ & 0.02 \\
\hline AmB-25 & 40 & $0.225 a$ & 0.05 & $0.289 a$ & 0.07 & $0.096 a$ & 0.02 \\
\hline AmB-50 & 40 & $0.124 a b$ & 0.06 & $0.189 a b$ & 0.05 & $0.048 \mathrm{ab}$ & 0.02 \\
\hline
\end{tabular}

Various lowercase letters - the differences are statistically significant for comparisons in the columns (between the control and AmB-25 and AmB-50) at $\mathrm{P} \leq 0.05$;

$\bar{x}$ - mean value;

\pm se - standard error;

shaded - the highest values of protein concentration;

AmB-25 - the workers were treated with $0.25 \mathrm{mg} / \mathrm{ml}$ amphotericin B;

AmB-50 - the workers were treated with $0.50 \mathrm{mg} / \mathrm{ml}$ amphotericin B.

No statistically significant differences were observed between the samples in a specific period

(7-8 samplings). 
methylation levels (Tab. 2). The influence of $\mathrm{AmB}$ on methylation increased along with the duration of the treatment and AmB doses.

Increased protein concentrations were observed in all the groups between the $3^{\text {rd }}$ and $4^{\text {th }}$ week (Tab. 3). The concentrations were higher in the case of AmB-50 and AmB-25 in comparison with the control, regardless of the AmB doses.

\section{DISCUSSION}

Amphotericin B is a life-saving antibiotic in human mycosis and, as confirmed by our study, an anti-Nosema spp protector in honeybees. Unfortunately, $\mathrm{AmB}$ is toxic to humans and forms concrements in the liver, kidneys, and the brain (Gagos et al., 2011). As we found, AmB is also deposited in honeybee hindguts (Fig. 1). Therefore, honeybees seems to be a good model for studying the mechanisms of this process. The new finding of this study was that AmB affects epigenetic control in the apian genome by reducing the global DNA methylation level (Tab. 2), probably by disturbing the methylation/demethylation equilibrium. A similar interrelationship was observed by Bardini et al. (2003) in a model plant Arabidopsis thaliana, following kanamycin administration. Changes in the genome methylation influence protein inhibitor synthesis and methylotransferase activity. This results in an altered metabolism (Bardini et al., 2003), with an effect on the lifespan (Burzyński, 2009). Senescence is a complex process connected with changes in many elements of numerous key metabolic pathways, and the honeybee is a unique known model in gerontology (Munch et al., 2008 and references therein). We found that $\mathrm{AmB}$ not only changed the DNA methylation level but also the lifespan of honeybees (Tab. 1). Hence, senescence acceleration may be considered as a side effect of treatment with AmB and probably also a side effect of treatment with other antibiotics. One of senescence symptoms is a reduction of protein synthesis, which was observed in this study in 5-week-old workers (Tab. 3).
We observed effects of AmB treatment on the apian cuticle protein concentrations. A dosage effect was additionally identified. A higher effect was observed for smaller doses in comparison with larger ones. This effect was also observed by Kang et al. (2002) in Drosophila. It turns out, that activity of the cuticle protein system may be alerted as a consequence of antibiotic therapy, which is similar to the results obtained during acaricide therapy against Varroa destructor in honeybees (How is et al., 2012; Strachecka et al., 2012a, b).

\section{CONCLUSION}

The honeybee proved a useful model for studies of the side effects of AmB therapy. The side effects of the therapy include epigenetic changes and senescence acceleration, accompanied by changes in the protein concentration.

\section{REFERENCES}

Bardini M., Labra M., Winfield M., Sala F. (2003) - Antibiotic-induced DNA methylation changes in calluses of Arabidopsis thaliana. Plant Cell, Tiss. Org. Culture, 72: 157-162.

Burzyński S. R. (2009) - Practical application of gene silencing theory of aging: life extension in animal testing and human clinical trials. Anti Ageing Medical Therapeutics, 11: 1-8.

Chorbiński P. (2004) - Control of chalkbrood disease of honey bee. Życie Wet., 79(11): 613-615.

De la Rua P., Jaffe R., Dall Olio R., Munoz I., Serrano J. (2009) Biodiversity, conservation and current threats to European honeybees. Apidologie, 40: 263284. DOI: 10.1051/apido/2009027.

Espada R., Valdespina S., Alfonoso C., Rivas G., Ballesterol M., Torrado J. (2008) - Effect of aggregation state on the toxicity of different amphotericin B preparations. Int. J. Pharm., 361(1-2): 64-69.

Gagoś M., Czernel G., Kamiński D., Kostro K. (2011) - Spectroscopic studies of amphotericin $\mathrm{B}-\mathrm{Cu}^{2+}$ complexes. Biometals, 24: 915-922. 
Gallis H., Drew R., Pickard W. (1990) - Amphotericin B: 30 years of clinical experience. Rev. Infect. Dis., 12 (2): 308-329.

Hartsel S., Bolard J. (1996) - Amphotericin B: new live for an old drug. Trends Pharmacol. Sci., 17: 445-449.

Howis M., Chorbiński P., Nowakowski P. (2012) - Physical damage to the chitin plate and position of Varroa destructor on hive bottoms after use of different varroacidal treatments. Med. Wet., 68(10): 607-611.

Kang H. L., Benzer S., Min K. T. (2002) - Life extension in Drosophila by feeding a drug. PNAS, 99 (2):838-843.

Konopka K., Guo L., Duzgunes N. (1999) - Anti-HIV activity of amphotericin B-cholesteryl sulfate colloidal dispersion in vitro. Antivir. Res., 42: 197-209.

Kostecka M., Niewiadomy A. (2010) Antifungal activity of new series of compound against Ascosphaera apis. Mikol. Lek., 17 (3): 169-171.

Krukowski H., Lisowski A., Szymankiewicz M. (2010) - Intensity of slime production by yeast strains isolated from bovine mastitis cases and their susceptibility to polyenes. Med. Wet., 66(9): 614-617.

Kucharski R., Maleszka J., Foret S., Maleszka R. (2008) - Nutritional control of reproductive status in honeybees via DNA Methylation. Science, 319 (5871): 1827-1830.

Lyko F., Maleszka R. (2011) - Insects as innovative models for functional studies of DNA methylation. Trends Genet., 27 (4): 127-164.

Maleszka R. (2008) - Epigenetic interaction of environmental and genomic signals in honey bee. Epigenetics, 3 (4): 188-192.

Munch D., Amdam G. V., Wolshin F. (2008) - Ageing in a eusocial insect: molecular and physiological characteristics of lifespan plasticity in honey bee. Funct. Ecol., 22: 407-421.
Paleolog J., Strachecka A., Burzyński S., Olszewski K., Borsuk G. (2011) - The larval diet supplemented with the low-molecular epigenetic switch sodium phenylacetylglutaminate influences the worker cuticle proteolytic system in Apis mellifera L. J. Apic. Sci., 55(2): 67-77.

Pohorecka K. (2004) - Choroby pszczół wywołane przez pierwotniaki, in: Podstawowe zasady diagnostyki, zwalczania i profilaktyki chorób czerwia - materiały szkoleniowe, Puławy, pp. 30-31.

Ptaszyńska A., Borsuk G., Anusiewicz M., Mułenko W. (2012a) - Location of Nosema spp. spores within the body of the honey bee. Med. Wet., 68(10): 618-621.

Ptaszyńska A., Borsuk G., Mułenko W., Olszewski K. (2012b) - Monitoring of nosemosis in the Lublin regionand preliminary morphometric studies of Nosema spp. spores. Med. Wet., 68(10): 622-625.

SAS Institute (2002-2003) SAS/STAT User's Guide release 9.13, Cary, NC, Statistical Analysis System Institute, license 86636.

Schacterle G., Pollack R. (1976) Simplified method for quantitative assay of small amounts of protein in biological material. Anal. Biochem., 51: 654 - 655.

Strachecka A., Paleolog J., Borsuk G., Olszewski K. (2012a) - Influence of formic acid on the body surface proteolytic system in different developmental stages of Apis mellifera L. workers. J. Apic. Res., 51(3): 252262. DOI: 10.3896/IBRA.1.51.3.06.

Strachecka A., Paleolog J., Olszewski K., Borsuk G. (2012b) Influence of amitraz and oxalic acid on the body surface proteolytic system of Apis mellifera L. workers. Insects, 3 (3): 821-832.

Strachecka A., Paleolog J., Borsuk G., Olszewski K., Bajda M. (2012 c) - DNA methylation in the honey bee (Apis mellifera) and its importance for biological research. Med. Wet., 68(7): 391-396. 


\title{
WPLYW AMFOTERYCYNY B NA DLUGOŚĆ ŻYCIA, STĘŻENIE BIALEK NA POWIERZCHNI CIALA I POZIOM METYLACJI DNA U PSZCZÓŁ (Apis mellifera)
}

\author{
Strachecka A., Borsuk G., Olszewski K., Paleolog J., \\ Gagoś M., Chobotow J., Nawrocka A., \\ Gryzińska M., Bajda M. \\ S t r e s z c z e n i e
}

Trzem grupom pszczół w klatkach podawano syrop cukrowy (grupa kontrolna), syrop cukrowy $\mathrm{z}$ dodatkiem amfoterycyny $\mathrm{B}(\mathrm{AmB}) \mathrm{w}$ dawce $0,5 \mathrm{mg} / \mathrm{ml}$ oraz syrop cukrowy z AmB w dawce $0,25 \mathrm{mg} / \mathrm{ml}$. AmB wpływała na skrócenie długości życia pszczół oraz obniżała poziom globalnej metylacji DNA w porównaniu do grupy kontrolnej, jednocześnie zwiększała stężenie białek na powierzchni ciała. AmB odkładała się w jelicie tylnym pszczół. Pszczoła miodna okazała się użytecznym modelem dla badań efektów ubocznych terapii antygrzybiczej z zastosowaniem AmB. Między innymi, za efekty uboczne takiej terapii uważa się zmiany epigenetyczne i przyspieszenie procesów starzenia.

Słowa kluczowe: amfoterycyna B, metylacja DNA, stężenie białka, długość życia, Apis mellifera. 